\title{
Public diplomacy in language education during the COVID-19 pandemic
}

\author{
Natalya Vladimirovna Yudina $^{1^{*}}$ and Oksana Aleksandrovna Seliverstova ${ }^{2}$ \\ ${ }^{1}$ Financial University under the Government of Russian Federation, Department of Foreign \\ Languages and Intercultural Communication, Moscow, Russia \\ ${ }^{2}$ Vladimir State University, Department of Foreign Languages for Professional Communication, \\ Vladimir, Russia
}

\begin{abstract}
The pandemic has had a considerable impact on all spheres of life. Likewise, it has affected all levels of education changing conventional interaction patterns. The new format of learning influenced the motivation on the whole and its components in particular. The paper presents results of the survey conducted among students of Linguistics that contains self-assessment of motivation for FL learning in general and at the time of pandemic during distance learning. The reported overwhelming opinion concerning the lack of proper communication in the new settings along with an overall decline in all types of motivation is forcing the faculty to look for new ways of encouraging language learning and compensate for the absence of face-to-face classes. In solving this problem, the resources of public diplomacy appeared to be a very helpful tool. The paper explores changes in the language learning process both from the teachers' and students' standpoint. It also gives a comparative overview of motivation types in conventional learning settings and distance-learning ones. The authors focus on the potential benefits of public diplomacy contacts in language learning.
\end{abstract}

Keywords: foreign language learning, language education, motivation, public diplomacy, distance learning, learning settings

\section{Introduction}

The transition to distance learning in the academic setting caused by the Covid-19 pandemic was fast and abrupt. While some courses appeared well suited for online learning, others had to undergo considerable changes to fit in the new settings. The latter is the case with FL courses for students of linguistic majors. Truth be told, the online format of language learning in itself is not new. However, students of linguistic majors treat and study English from a professional perspective. It implies an in-depth study of specific language issues and practice that require face-to-face interaction. Thus, the transition to distance learning required a considerable degree of adaptation. Direct observation of students' attitudes and progress made us think of a complete transformation of motivation and related

*Corresponding author: $\underline{\text { dr.vudina@mail.ru }}$ 
outcomes in terms of language proficiency. It encouraged us to conduct a survey to reveal the students' self-assessment of motivation in general and one during distance learning.

According to Gardner, we can distinguish between three components of motivation integarativeness, instrumentality and attitudes to learning situation [1]. Integrativeness is linked to "a genuine interest in learning the second language in order to come closer to the other language community" [2], instrumentality implies "learning an L2 for pragmatic reasons, such as getting a better job or a higher salary" [3]. Attitudes to the learning situation involve 3 sets of motivational components: 1) course-specific - concerning the syllabus, the teaching materials, the teaching method, and the learning tasks; 2) teacher-specific - concerning the teacher's personality, teaching style, feedback, and relationship with the students; 3) group-specific - concerning the dynamics of the learning group [4].

Another type of motivation is the need for achievement or performance commitment and failure avoidance. Failure avoidance involves a dislike of evaluative situations and a fear of failing [5]. With regard to FLL situations of avoiding communication with native speakers or foreigners due to a language barrier may be considered an example of failure avoidance. Likewise, accomplishing the tasks with a view to avoid bad grades reveals a combination of extrinsic motivation with that of failure avoidance. The opposite of failure avoidance is the need for achievement. Individuals with a high need for achievement are interested in excellence for its own sake, tend to initiate achievement activities, work with heightened intensity at these tasks, and persist in the face of failure" (ibid.)

\section{Methods}

In order to give a full account of changes in the motivation structure, we conducted a survey among students of Linguistics at Vladimir State University (Russia) that involved 55 respondents.

Table 1 presents the components of the motivation model and used for self-assessment by the students.

Table 1. Components and Indicators of FL Motivation.

\begin{tabular}{|c|c|c|}
\hline \multirow{5}{*}{$\begin{array}{l}\text { Language-rel } \\
\text { ated }\end{array}$} & \multirow{3}{*}{ Integrativeness } & Interest in the culture and history of FL countries \\
\hline & & Desire for new knowledge accessible in FL \\
\hline & & Desire for communication with foreigners \\
\hline & \multirow{2}{*}{ Instrumentality } & Travel motivation \\
\hline & & Potentially better career prospects \\
\hline \multirow{3}{*}{$\begin{array}{l}\text { Learning-rel } \\
\text { ated }\end{array}$} & Course-specific & Appeal of the syllabus, course structure, and materials \\
\hline & $\begin{array}{l}\text { Teacher-specifi } \\
\text { c }\end{array}$ & Teacher's personality, approach, individual teaching style \\
\hline & Group-specific & Desire to communicate and work together with group-mates \\
\hline \multirow{3}{*}{$\begin{array}{l}\text { Learner-relat } \\
\text { ed }\end{array}$} & $\begin{array}{l}\text { Performance } \\
\text { commitment }\end{array}$ & Desire to get good and excellent grades \\
\hline & \multirow{2}{*}{$\begin{array}{l}\text { Failure } \\
\text { avoidance }\end{array}$} & Necessity to meet tough control demands to avoid bad marks \\
\hline & & Necessity to complete the course to get to the next year of study \\
\hline
\end{tabular}

The survey structure included 3 parts: the first being related to the overall motivation self-assessment, the second one was designed to describe communication experience with 
native-speakers and its effects on language learning motivation as well as the perceived need for that; the third one was aimed at evaluation of distance learning experience in FL learning.

The full questionnaire offered to the respondents is available at the link [6].

\section{$3 \quad$ Results}

For interpreting the results, we assumed the points $0-1$ to mark a low level, points 2-3 a mid-level and 4-5 a high level of motivation. Predictably enough, the highest motivation was shown by language-related components, career prospects being on top with $93.1 \%$ of respondents reporting a high level of motivation, closely followed by the desire for communication with foreigners $(92.7 \%)$. Detailed results for all indicator types are presented in table 2 .

Table 2. Motivation self-assessment results.

\begin{tabular}{|c|c|c|c|c|c|c|c|c|}
\hline \multirow[t]{2}{*}{$\begin{array}{l}\text { Motivation } \\
\text { component }\end{array}$} & \multirow[t]{2}{*}{ Type } & \multirow[t]{2}{*}{ Indicator } & \multicolumn{3}{|c|}{$\begin{array}{c}\text { Motivation } \\
\text { self-assessment, \% }\end{array}$} & \multicolumn{3}{|c|}{$\begin{array}{c}\text { Motivation } \\
\text { self-assessment (in } \\
\text { distance learning), } \\
\%\end{array}$} \\
\hline & & & $0-1$ & $2-3$ & $\overline{4-5}$ & 0-1 & $2-3$ & $44-5$ \\
\hline \multirow{5}{*}{$\begin{array}{l}\text { Language-r } \\
\text { elated }\end{array}$} & \multirow{3}{*}{ Integrativeness } & $\begin{array}{l}\text { Interest in the } \\
\text { culture and history } \\
\text { of FL countries }\end{array}$ & 3.65 & 16.35 & 80 & 16.7 & 22.2 & 61.1 \\
\hline & & $\begin{array}{l}\text { Desire for new } \\
\text { knowledge } \\
\text { accessible in FL }\end{array}$ & 1.8 & 12.8 & 85.4 & 9.2 & 18.5 & 70.3 \\
\hline & & $\begin{array}{l}\text { Desire for } \\
\text { communication } \\
\text { with foreigners }\end{array}$ & 3.6 & 3.6 & 92.7 & 15.1 & 20.7 & 64.2 \\
\hline & \multirow[b]{2}{*}{ Instrumentality } & Travel motivation & 1.8 & 14.6 & 83.6 & 20.4 & 13 & 66.7 \\
\hline & & $\begin{array}{l}\text { Potentially better } \\
\text { career prospects }\end{array}$ & 0 & 7.3 & 93.1 & 11.1 & 20.4 & 68.5 \\
\hline \multirow{3}{*}{$\begin{array}{l}\text { Learning-re } \\
\text { lated }\end{array}$} & Course-specific & $\begin{array}{l}\text { Appeal of the } \\
\text { syllabus, course } \\
\text { structure, and } \\
\text { materials }\end{array}$ & 9.1 & 27.3 & 63.7 & 38.1 & 34.5 & 25.5 \\
\hline & Teacher-specific & $\begin{array}{l}\text { Teacher's } \\
\text { personality, } \\
\text { approach, } \\
\text { individual } \\
\text { teaching style }\end{array}$ & 7.2 & 16.3 & 76.3 & 18.2 & 32.7 & 49.1 \\
\hline & Group-specific & $\begin{array}{l}\text { Desire to } \\
\text { communicate and } \\
\text { work together } \\
\text { with group-mates }\end{array}$ & 5.5 & 14.6 & 80 & 18.5 & 38.9 & 42.6 \\
\hline \multirow{2}{*}{$\begin{array}{l}\text { Learner-rel } \\
\text { ated }\end{array}$} & $\begin{array}{l}\text { Performance } \\
\text { commitment }\end{array}$ & $\begin{array}{l}\text { Desire to get good } \\
\text { and excellent } \\
\text { grades }\end{array}$ & 16.4 & 32.7 & 50.9 & 25.9 & 40.8 & 33.3 \\
\hline & $\begin{array}{l}\text { Failure } \\
\text { avoidance }\end{array}$ & $\begin{array}{l}\text { Necessity to meet } \\
\text { tough control } \\
\text { demands to avoid } \\
\text { bad marks }\end{array}$ & 9.1 & 50.9 & 30 & 27.8 & 50 & 22.2 \\
\hline
\end{tabular}




\begin{tabular}{|l|l|l|l|l|l|l|l|l|}
\hline & $\begin{array}{l}\text { Necessity to } \\
\text { complete the } \\
\text { course to get to } \\
\text { the next year of } \\
\text { study }\end{array}$ & 12.7 & 29.1 & 58.2 & 22.2 & 27.8 & 50 \\
\hline
\end{tabular}

As seen from table 2, the top high-level motivation indicators saw a substantial decline during distance learning losing about $25-29 \%$ of their value. The same is true for learning-related indicators that dropped by nearly $50 \%$ on average. The most significant decline is shown by course-related motivation (a drop from 63.7 to $25.5 \%$ ) which may be evidence of the importance of face-to-face work in class and the problem of proper adaptation of FL courses to distance learning settings. Interestingly enough, learner-related motivation, especially failure avoidance remained rather stable.

Assessment of communication opportunities showed that $10.3 \%$ have not had any experience. Among those who have, there is a considerable prevalence of personal contacts over those offered by the university. Even taken together, off-line and online communication opportunities provided by university staff and faculty make up $68.9 \%$ lagging behind personal contacts by over $10 \%$. A detailed account of the communication opportunities assessment is presented in Fig. 1.

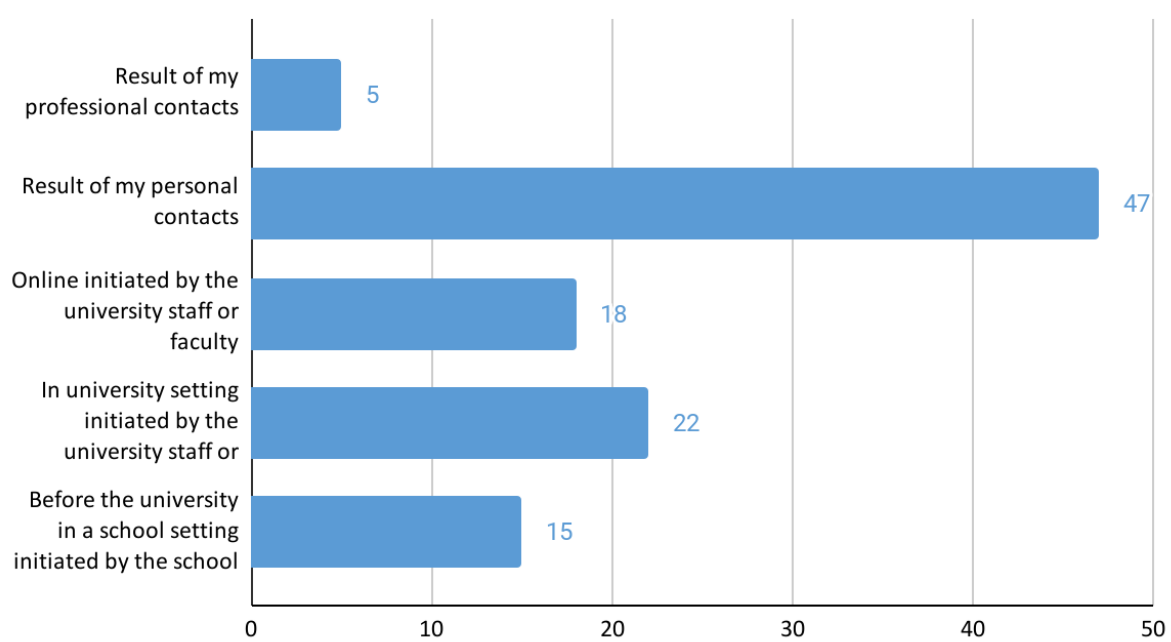

Fig. 1. Where does your communication experience stem from?

Assessing the FL communication opportunities and their availability in university settings more than half of the respondents $(54.5 \%)$ said that communication opportunities are available but not enough, with $25.5 \%$ claiming the opportunities are scarce or unavailable. Combined these values make up $80 \%$ of unsatisfied students, with only $9.1 \%$ saying that they are content, $9.1 \%$ saying they do not use the opportunities offered and $1.8 \%$ blaming the lack of opportunities on the pandemic.

The assessment of changes in learning time distribution across four language aspects showed that most of the respondents noticed an increase in writing with time for reading remaining unchanged. Listening and speaking reveal controversial results with answers "decreased" and "remained unchanged" representing approximately the same values. A 
closer look at answer distribution shows that respondents who chose answers "remained unchanged" or "increased" with regard to speaking also had high course-specific motivation, which did not decline after transition to distance learning. This observation highlights a direct connection between speaking and high level of course-specific motivation. It is predictable enough given the initially high level of motivation linked to students' desire for communication with foreigners and desire to communicate and work together with group-mates. The opposite correlation is also true - in classes with decreased speaking time the motivation values showed a greater decline.

Providing a feedback about the distance learning experience among the most frequent answers were lack of live communication with faculty and fellow-students, connection issues during online-classes, increased amount of autonomous learning. Truth be told, some respondents reported autonomous learning a benefit of distance learning format. Among other advantages, students mentioned extra time because one did not have to commute, flexible schedules, new assignment types and useful online resources. However, $14.5 \% \mathrm{did}$ not report any advantages saying they did not like the experience.

\section{Discussion}

The results of the survey showed the degree of emphasis placed by students on communication in class both with professors and other students, as well as with native speakers. The lack of it leads to declining motivation across all three components. The fact that personal contacts overweigh those initiated by university staff and faculty shows the students' motivation to practice FL and the demand for more international contacts stemming from the university connections.

In view of the above public diplomacy might be a good solution to the problem. The terms soft power and public diplomacy have received much attention in the past two decades in scientific and political discourse. The former introduced by J. Nye has undergone changes evolving from "the ability to establish preferences associated with intangible resources such as culture, ideology, and institutions" to "the ability to affect others through the co-optive means of framing the agenda, persuading, and eliciting positive attraction in order to obtain preferred outcomes" [7-9]. The connection between language promotion and soft power has been studied [10-13] to reveal the potential benefits and aspirations of external language policy and planning. However, the reverse impact of language promotion efforts of the actor country on education opportunities in the 'recipient' country has not been given due attention so far. Individual efforts $[14,15]$ to approach the topic show its research and practical potential. A keen observation that "modern public diplomacy is a 'two-way street' referring to persuasion by means of dialogue and listening to what people have to say [16] can be extended to represent language promotion as 'a two-way street' as well.

Due to the efforts of governments to reach large audiences abroad with either propaganda or public diplomacy efforts, the latter has received a negative connotation. The desire for large scale and fast results that governments strive for is often confronted by resistance from other countries' governments trying to curtail any undesirable influence. The idea of the changing face of public diplomacy with the development of relations between civil society actors abroad and at home coming to the forefront is highlighted in recent studies $[17,18]$. So, if we descend to a grass-root level, individual efforts prove to bring a lot more fruitful results in establishing mutual understanding, respect and cross-cultural awareness which embodies the idea of "a two-way street" to the full. 


\section{Conclusion}

Thus, the involvement of FL faculty into public diplomacy on a lower level can potentially create new and interesting communication opportunities for students. With FL teachers initiating these opportunities, such communication is likely to provide a better level of FL education, satisfy the existing demand, foster motivation and promote better professional growth along with developing cross-cultural competence.

\section{References}

1. R.C. Gardner, The Attitude/Motivation Test Battery: Technical Report (Univ. of Western Ontario, London, 1985)

2. R.C. Gardner, Integrative motivation and second language acquisition, in Z. Dörnyei, R. Schmidt (eds), Motivation and Second Language Acquisition, 1-19. (University of Hawaii Press, Hawaii, 2001)

3. H.Y.T. Lai, Int Edu Stud, 6(10), 90-101 (2013). http://dx.doi.org/10.5539/ies.v6n10p90

4. Z. Dornye, Mod Lang J, 78(3), 273-284 (1994). https://doi.org/10.2307/330107

5. S.R. Heimerdinger, V.B. Hinsz, Human Perf, 21, 383-395 (2008). https://doi.org/10.1080/08959280802347155

6. Survey 2021. Accessed on: October 8, 2021. [Online]. Available: https://docs.google.com/spreadsheets/d/1XOvxtIcNBmbE_gWG28zA38wYH8tDyk0e Re16O2McvlE/edit?usp=sharing

7. J.S. Nye, The Future of Power (Public Affairs, New York, 2011)

8. J.S. Nye, Bound to Lead: The Changing Nature of American Power (Basic Books, New York, 1990)

9. J.S. Nye, Soft Power. The Means to Success in World Politics (Public Affairs, New York, 2004)

10. E. L. Hernández, J Contemp East Asia, 17(1), 27-49, (2008). https://doi.org/10.17477/jcea.2018.17.1.027

11. G. Pashaeva, Lang Prob Lang Plan, 42(2), 132-143 (2018). https://doi.org/10.1075/lplp.00016.pas

12. N.V. Yudina, O.A. Seliverstova, External Language Policy and Planning, in Proceedings of the IV International Scientific and Practical Conference 'Anthropogenic Transformation of Geospace: Nature, Economy, Society' (ATG 2019), 309-314 (2020). https://doi.org/10.2991/aer.k.200202.063

13. N.V. Yudina, M.V. Melnichul, O.A. Seliverstova, J Soc Stud Edu Res, 11(3), 242-269 (2020)

14. R. Moutinho, Multicult Edu Rev, 7(1-2), 85-98 (2015). https://doi.org/10.1080/2005615X.2015.1061920

15. M. Akli, Int Res Rev: J Phi Beta Delta Honor Society Int Schol, 2(1), 32-48 (2012)

16. J. Melissen, The New Public Diplomacy. Soft power in international relations (Palgrave Macmillan, Basingstoke, 2005) 
17. K. Pisarska, The Domestic Dimension of Public Diplomacy. Evaluating success through civil engagement (Palgrave Macmillan, London, 2016)

18. N. Snow, N.J. Cull, (ed), Routledge Handbook of Public Diplomacy. (Routledge, New York, 2020) 